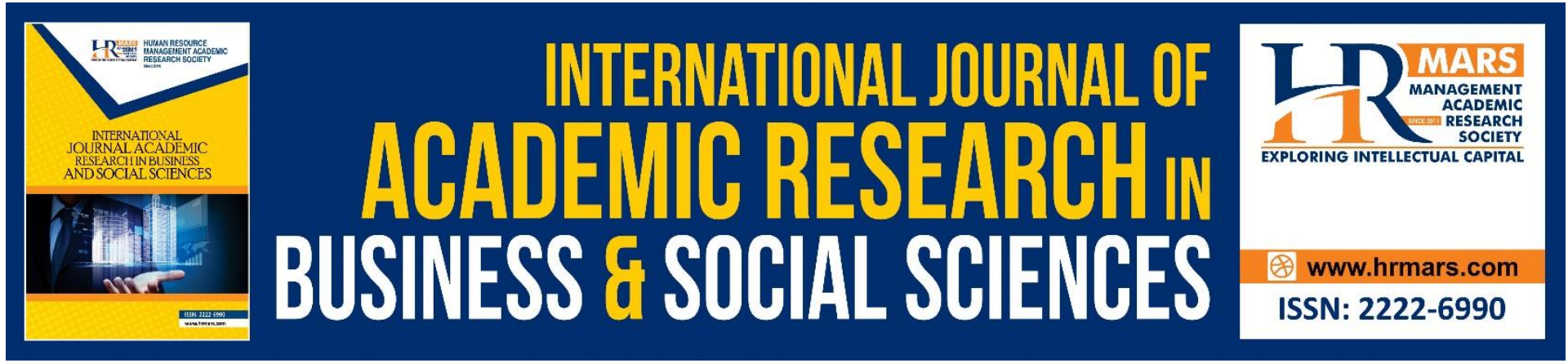

\title{
The Relationship between Extrinsic Rewards and Employee Performance: A Mediating Role of Employee Job Satisfaction
}

\section{Md Murad Miah, Nor Intan Adha Hafit}

To Link this Article: http://dx.doi.org/10.6007/IJARBSS/v11-i7/10471

DOI:10.6007/IJARBSS/v11-i7/10471

Received: 20 May 2021, Revised: 22 June 2021, Accepted: 10 July 2021

Published Online: 25 July 2021

In-Text Citation: (Miah \& Hafit, 2021)

To Cite this Article: Miah, M. M., \& Hafit, N. I. A. (2021). The Relationship between Extrinsic Rewards and Employee Performance: A Mediating Role of Employee Job Satisfaction. International Journal of Academic Research in Business and Social Sciences, 11(7), 485-496.

\section{Copyright: @ 2021 The Author(s)}

Published by Human Resource Management Academic Research Society (www.hrmars.com)

This article is published under the Creative Commons Attribution (CC BY 4.0) license. Anyone may reproduce, distribute, translate and create derivative works of this article (for both commercial and non-commercial purposes), subject to full attribution to the original publication and authors. The full terms of this license may be seen at: http://creativecommons.org/licences/by/4.0/legalcode

Vol. 11, No. 7, 2021, Pg. $485-496$

Full Terms \& Conditions of access and use can be found at http://hrmars.com/index.php/pages/detail/publication-ethics 


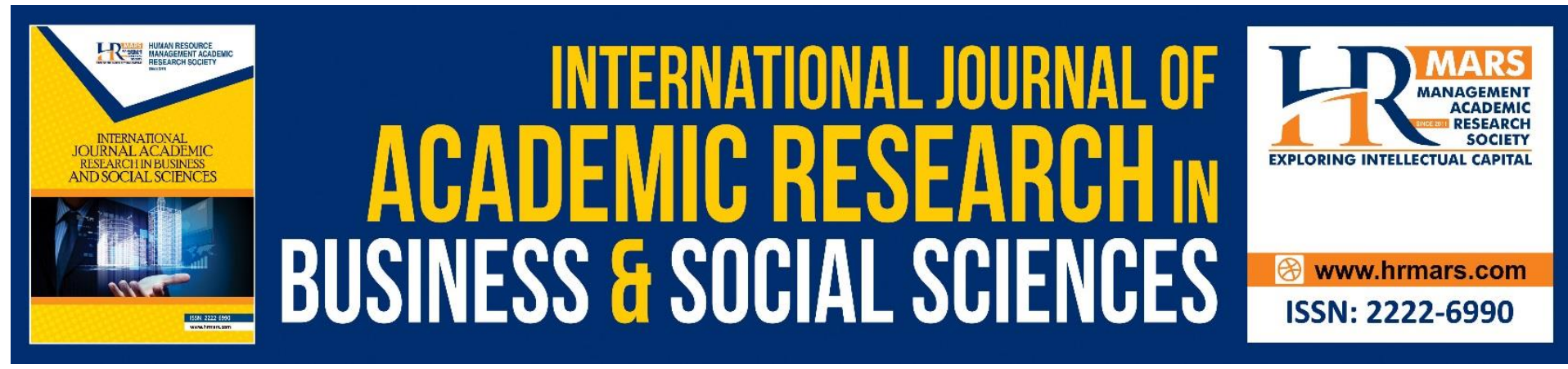

\title{
The Relationship between Extrinsic Rewards and Employee Performance: A Mediating Role of Employee Job Satisfaction
}

\author{
Md Murad Miah, Nor Intan Adha Hafit \\ Faculty of Business and Management, Universiti Teknologi MARA (UiTM), 40450 Shah Alam, \\ Selangor, Malaysia. \\ Email: muradmiah1996@gmail.com
}

\begin{abstract}
Food and Beverage industry is inconceivably competitive in case compared to other industries in Malaysia. Each player in this industry regularly endures from challenges in moving forward the standards and inventing their food offerings in order to pull in more customers. To achieve this objective, the workforce of the front line is exceptionally highly imperative since without the fine quality of food, and superb customer service the F\&B business cannot preserve itself within the market. This is often, staff job satisfaction and the highest level of job performance are essential which may affect from the various factors within the organization. One of the reasonable factors is extrinsic rewards that can motivate F\&B staff to satisfy their job and upgrade their performance. Hence, there is a need to investigate the impact of extrinsic rewards on job satisfaction, and job performance among employees of the food and beverage industry in Malaysia. The sample of this study was 60 employees in Sunway city. The quantitative research method was utilized, and data collection used to be carried out by using an open-ended questionnaire survey. SPSS 23 software was used to analyse the data of this study. In addition, PROCESS Macro analysis was used to conduct the mediating analysis. The result of the study concludes with clear evidence that extrinsic rewards have a week positive and significant relationship with job satisfaction, and employee performance. On the other hand, job satisfaction has a non-significant and too low negative relationship with employee performance. Last but not least, the result also discovered that job satisfaction does not have any influence on the relationship between extrinsic rewards and employee performance.
\end{abstract}

Keywords: Extrinsic Rewards, Job Satisfaction, Employee Performance, Food \& Beverage Industry.

\section{Introduction}

Malaysians' love for food has created a massive market in the food and beverage (F\&B) industry. F\&B services recorded a gross output value of RM82.8 billion in 2017 as in contrast to RM66.4 billion in 2015, with an annual growth rate of 11.7 per cent (Department of Statistics Malaysia, 2018). In addition, Food offerings registered the highest range of persons engaged of 758,992 persons or 79.2 per cent (2015: 79.7\%). The second highest contributor 
was event catering offerings with 106,701 persons or 11.1 per cent (2015: 11.2\%), followed by the aid of beverage services with 93,110 persons or 9.7 per cent (2015: 9.2\%) (Department of Statistics Malaysia, 2018)

According to Hall (2010), the front-line employees have contributed immediately to an organization's competitive advantage, and it will be a serious impact on its bottom line. He also stated that the employees' work performance in the food industry would directly lead to customer satisfaction or dissatisfaction in view that they are the ones who face directly with customers. Thus, employees are the backbone of the food and beverage industry and a fundamental human asset to function the $F \& B$ business smoothly. F\&B business requires employees to observe their skills in their works and deliver the best performance to drive the companies in the direction of achieving their objectives and goals. Dienhart and Downey (1992) mentioned that "Service-oriented personnel are important to every job in a food service organization due to the fact they promote the organization's public image and the quality of life in the workplace".

According to the Central bank of Malaysia annual report (2018), Malaysian workers are being less paid than their other regional peers, such as those in Singapore and South Korea. By pointing this situation, the report additionally mentions that if a Malaysian worker produces output worth US\$1,000, the worker will be paid US\$340 for it. However, Bank Negara Malaysia annual report also stated that F\&B industry personnel are not being paid ample via the organization. The report additionally referred to the cause that in the F\&B industry working low and medium-skilled workers those who cannot exhibit sufficient bargaining power with the organization, this is because, the employer is taking advantage of it. According to Riasat, Aslam, and Nisar (2016), extrinsic rewards play an important function in worker job satisfaction and job performance. They point out that if personnel of the food industry perceive comparable monetary rewards it affects their excessive job satisfaction. On the other hand, when employees identify that they are less paid than those who work in a comparable role in other companies it negatively influences their work feeling and negatively affects job performance (Joo-Ee, 2016). Based on the scenario of the Malaysian food service industry we observed that they have a notably and continuous growing contribution toward Malaysian GDP, however, the primary asset of the food and beverage industry as employees is less concerned by previous academics and practitioners (Joo-Ee, 2016; Abdullah \& Othman, 2019).

As we overlook, extrinsic rewards provide extrinsic motivation and more reliable with employee job satisfaction, and overall performance of the F\&B Industry. This is because, this study investigates the relationship between extrinsic rewards, job satisfaction, employee performance of the Food and Beverage Industry in Sunway city of Malaysia.

\section{Theoretical Framework}

In this study, the social exchange theory (Blau, 1964) was utilized to support the relationship between extrinsic rewards, job satisfaction, employee performance. Social exchange theory applies to the workplace. It is one of the most influential conceptual paradigms in organizational behaviour. This theory shows the perfect sense because employees spend so much of their lives at their jobs. Work is a give and take. Everyone has hit the wall at one factor or some other and questioned whether sticking around at a company was worth it. 
According to Gould-Williams and Davies (2005), when employers offer socio-emotional or financial rewards towards employees, thus, with recognition to reciprocity, employees is feeling positive about their job and provide effective work performance. Thus, social exchange theory is utilized to assist the relationship of extrinsic rewards, job satisfaction, employee performance. In addition, the researcher added a few relevant models to draw the conceptual framework and development of hypotheses.

Kilimo, Namusonge, and Makokha (2017) performed research on the relationship of extrinsic rewards on employee performance among 60 employees of Tea Factory Company Trans Nzoia County Kenya, the findings of the study concluded with clear proof that extrinsic rewards have a positive significant relationship with employee performance.

Khan, Shahid, Nawab, and Wali (2013) conducted research about the impact of intrinsic rewards and extrinsic rewards on employee performance among 165 employees of the private bank sector of Pakistan, the result of the study found that extrinsic rewards positively influence employee performance.

Riasat, Aslam, and Nisar (2016) carried out research about the effect of extrinsic rewards, job satisfaction, and job performance among nursing staff in hospitals of Malaysia. The researcher concludes with clear evidence indicated that extrinsic rewards positively have an effect on job satisfaction and employee performance. Based on this study, the researcher utilizes job satisfaction as mediating variable on the relationship between extrinsic rewards and employee performance.

Based on the above theoretical development, the following conceptual framework and hypotheses were developed:

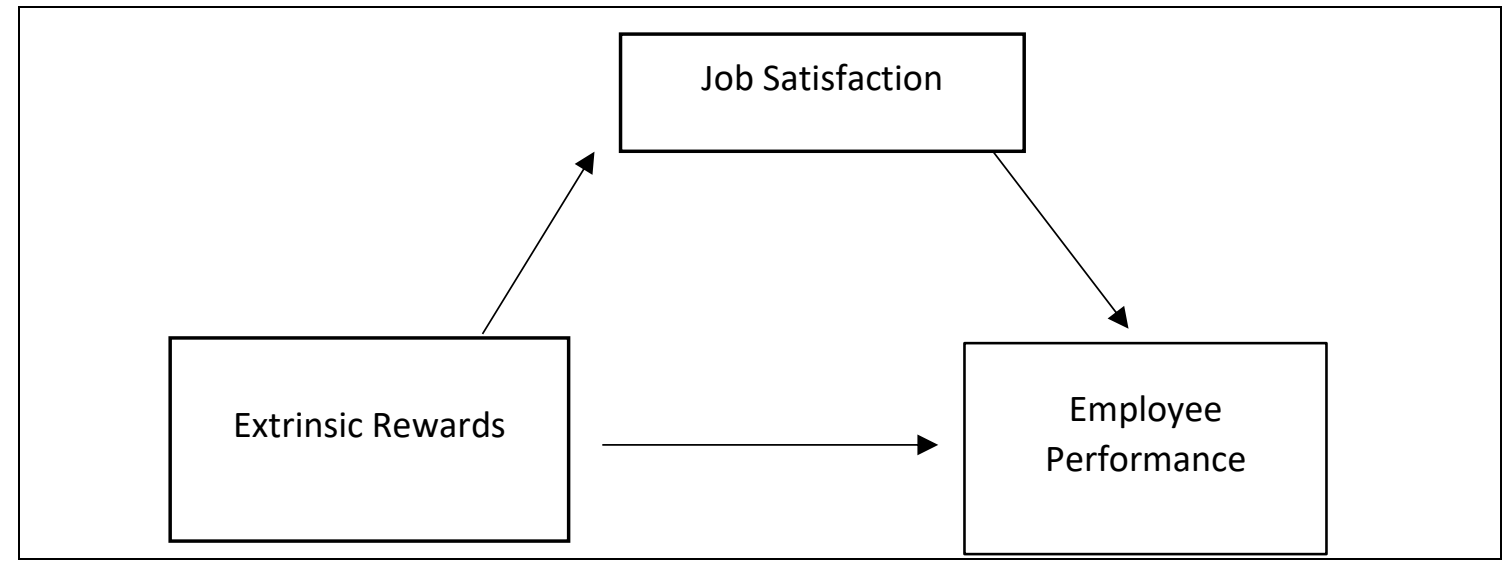

Figure 1: Conceptual Framework

H1: Extrinsic Rewards has a positive significant relationship with job satisfaction.

$\mathrm{H} 2$ : Job satisfaction has a positive significant relationship with employee performance.

H3: Extrinsic rewards have a positive relationship with employee performance.

$\mathrm{H} 4$ : Job satisfaction has a mediating effect on the relationship between extrinsic rewards and employee performance.

\section{Methodology}

Sample

To investigate the relationship between extrinsic rewards, job satisfaction, and employee performance among Food \& Beverages industry in Sunway City, whose exact numbers have 
not been ascertained, so the minimum numbers of samples are 5 times the number of indicators. Because there are 11 indicators in this study, the number of samples is a minimal of 55 With a complete of 60 respondents, they have met the minimum sample limit (Hair et al., 2010).

\section{Measurement}

Extrinsic rewards use five items which were adapted from Robinson et al. (1969) and Clifford (1985). The items of these scales were modified accordingly to the present stage, due to our societal changes. Clifford (1985) recorded reliability via Cronbach's alpha which yielded reliability coefficients of 0.822 and 0.821 for the two scales respectively on organizational rewards and social rewards. This scale uses 5 -point Likert scale to ensure the degree of agreement which varies from 1-5 respectively, 1- strongly disagree, 2- disagree, 3- neutral, 4agree, 5- strongly agree.

Job Satisfaction was developed from three commonly used global items. This scale was used and examined by (Clifford, 1985). Clifford (1985) suggested reliability by Cronbach's alpha which yielded 0.772 . Job satisfaction also uses 5 - point Likert scale to ensure the degree of agreement which varies from 1-5 respectively, 1- strongly disagree, 2- disagree, 3- neutral, 4agree, 5- strongly agree.

Employee Performance use three items that had been adopted from Ramli (2018). Based on the previous study, Ramli (2018) recorded a Cronbach alpha value of 0.822 . For this scales additionally utilize 5 - point Likert scale to ensure the diploma of agreement which varies from 1-5 respectively, 1- strongly disagree, 2- disagree, 3- neutral, 4- agree, 5- strongly agree.

\section{Data Collection Technique}

This study uses the quantitative method of data collection which was a questionnaire form of survey. It was an open-ended questionnaire and face to face data collection. 


\section{Analysis}

\section{Demographic Profile}

Table 1: The Result of Demographic Profile.

\begin{tabular}{|c|c|c|c|}
\hline No. & & Frequency & Percentage (\%) \\
\hline \multirow[t]{3}{*}{1.} & Gender & & \\
\hline & Male & 34 & 56.7 \\
\hline & Female & 26 & 43.3 \\
\hline \multirow[t]{3}{*}{2.} & Marital Status & & \\
\hline & Single & 35 & 58.3 \\
\hline & Married & 25 & 41.7 \\
\hline \multirow[t]{5}{*}{3.} & Age & & \\
\hline & $18-22$ years & 6 & 10.0 \\
\hline & $23-27$ years & 26 & 43.3 \\
\hline & $28-32$ years & 24 & 40.0 \\
\hline & 33-37 years & 4 & 6.7 \\
\hline \multirow[t]{4}{*}{4.} & Academic Qualification & & \\
\hline & SPM/SSC & 13 & 21.7 \\
\hline & Diploma/HSC & 31 & 51.7 \\
\hline & Bachelor's degree & 16 & 26.7 \\
\hline \multirow[t]{3}{*}{5.} & Types of Employment & & \\
\hline & Full-Time & 49 & 81.7 \\
\hline & Part-Time & 11 & 18.3 \\
\hline \multirow[t]{8}{*}{6.} & Designation & & \\
\hline & Ast.Manager & 12 & 20.0 \\
\hline & Supervisor & 10 & 16.7 \\
\hline & Floor Captain & 8 & 13.3 \\
\hline & Chef & 4 & 6.7 \\
\hline & Ast. Chef & 8 & 13.3 \\
\hline & Kitchen Helper & 4 & 6.7 \\
\hline & Waitress/Waiter/Cashier & 14 & 23.3 \\
\hline \multirow[t]{7}{*}{7.} & Monthly Income & & \\
\hline & RM $1200-$ RM 1500 & 7 & 11.7 \\
\hline & RM $1600-$ RM 1900 & 17 & 28.3 \\
\hline & RM $2000-$ RM 2300 & 14 & 23.3 \\
\hline & RM $2400-$ RM 2900 & 9 & 15.0 \\
\hline & RM $3000-$ RM 3300 & 12 & 20.0 \\
\hline & RM $2400-$ RM 3900 & 1 & 1.7 \\
\hline \multirow[t]{3}{*}{8.} & Nationality & & \\
\hline & Malaysian & 23 & 38.3 \\
\hline & Non-Malaysia & 37 & 61.7 \\
\hline
\end{tabular}

Based on table (1) In this study, male respondents was 34 with the per cent of $56.7 \%$, and female was 26 respondents with the per cent of $43.3 \%$. From the marital status and, age group, the maximum number of the respondent used to be single, and most are 23-27 years old with the per cent of $43.3 \%$. In addition, most of the respondents were diploma/HSC academic qualification level, and the maximum number of the respondent was the full-time staff. The position of employees responds in this study from a group of 'waitress/waiter/casher' with the per cent of $23 \%$. Monthly income of respondents often 
indicates 'RM 1600 - RM 1900' with the frequency of 17 and per cent of $28.3 \%$. Last but not least, interestingly, in this study, mostly respondent was non-Malaysian with the frequency of 37 and per cent of $61.7 \%$.

Thus, from the demographic profile, it is clear that in the $F \& B$ industry mainly male employees are dominating the fundamental part, and young age are mostly working from the range of 23- 32 years. From the demographic profile, it also shows that the 'monthly income' of personnel of Sunway city is very low than other industry. Finally, the demographic profile also most curiously shows that most of the staff are foreign employees in the F\&B industry in Sunway city.

Factor Analysis

Table 2: The Result of KMO and Bartlett's Test

\begin{tabular}{lll}
\hline \multicolumn{3}{l}{ KMO and Bartlett's Test } \\
\hline \multicolumn{3}{l}{ Kaiser-Meyer-Olkin Measure of Sampling Adequacy. } \\
\hline Bartlett's Test & of Approx. Chi-Square & .666 \\
\cline { 2 - 3 } Sphericity & Df & 267.166 \\
\cline { 2 - 3 } & Sig. & 55 \\
\hline
\end{tabular}

Based on table (2) shows that the KMO value more than .60, the MSA value for each item was more than .50 , and bartlett's test Sphericity was $\mathrm{P}<0.05$, which consider factor analysis was suitable for this study (Hair, Black, Babin, Anderson, \& Tatham, 2006). In addition, the total variance defined by each item should be more than $60 \%$, to maintain the requirement of factor analysis (Hair et al., 2006). Meanwhile, in this study total variance of the factor was more than $68.15 \%$, thus, this study is valid for future analysis.

Reliability Analysis

Table 3: The Result of Reliability Analysis

\begin{tabular}{lllll}
\hline No. & Variable & Indicator Item & Cronbach alpha & Information \\
\hline 1. & Extrinsic Rewards & 5 & 0.817 & Reliable \\
\hline 2. & Job Satisfaction & 3 & 0.831 & Reliable \\
\hline 3. & Employee Performance & 3 & 0.801 & Reliable \\
\hline
\end{tabular}

Table (3) shows the result of the reliability analysis of this study. Based on the analysis, it shows that all the three variables Cronbach's Alpha value of more than .70, which indicate that all the items of the variable are highly reliable for this study. From reliability analysis, Cronbach's Alpha value range from 0.801 to 0.831 . From three variables, Job satisfaction consists of the highest Cronbach's Alpha value of 0.831 . 


\section{Correlation Analysis}

Table 4. The Result of Correlation Analysis

\begin{tabular}{|c|c|c|c|c|c|}
\hline & & & ER & JS & EP \\
\hline \multirow[t]{6}{*}{$\begin{array}{l}\text { Spearman's } \\
\text { rho }\end{array}$} & ER & $\begin{array}{l}\text { Correlation } \\
\text { Coefficient }\end{array}$ & & & \\
\hline & & Sig. (1-tailed) & & & \\
\hline & JS & $\begin{array}{l}\text { Correlation } \\
\text { Coefficient }\end{array}$ & $.261^{*}$ & & \\
\hline & & Sig. (1-tailed) & .022 & & \\
\hline & EP & $\begin{array}{l}\text { Correlation } \\
\text { Coefficient } \\
\end{array}$ & $.228^{*}$ & -.055 & \\
\hline & & Sig. (1-tailed) & .040 & .340 & \\
\hline
\end{tabular}

*. Correlation is significant at the 0.05 level (1-tailed).

Based on the normality test, the researcher was found that data was non-normality distribution. This is because, non-parametric test as spearman's correlation was utilized to examine the relationship between independent, mediator, dependent variables.

The result of the correlation analysis shows that extrinsic rewards have a weak positive significant correlation with employee performance $\left(r_{s}=.228\right)$. In addition, Extrinsic rewards also have a weak and positive significant correlation with job satisfaction $\left(r_{s}=.261\right)$. On the other hand, Job satisfaction has a non -significant, too low negative correlation with employee performance $\left(r_{s}=-.055\right)$.

Mediating Analysis (PROCESS Macro Analysis) Table 5: The Result of PROCESS Macro Analysis

\begin{tabular}{|c|c|c|c|c|c|c|c|}
\hline Variable & & Path A & Path B & Path C & Path C' & $\begin{array}{l}\text { Indirect } \\
\text { Effect }\end{array}$ & $\begin{array}{l}\text { Completely } \\
\text { Standardize } \\
\text { Indirect } \\
\text { Effect }\end{array}$ \\
\hline Extrinsic & Coeff. & .1932 & -.1522 & .1327 & .1621 & BootLLCI & BootLLCI \\
\hline Rewards & $\begin{array}{c}\text { s.e. } \\
\text { p. }\end{array}$ & $\begin{array}{l}.0915 \\
.0389\end{array}$ & $\begin{array}{l}.1319 \\
.2532\end{array}$ & $\begin{array}{l}.0921 \\
.1551\end{array}$ & $\begin{array}{l}.0953 \\
.0945\end{array}$ & $\begin{array}{l}-0.0771 \\
\text { BootULCI } \\
.0174\end{array}$ & $\begin{array}{l}-.1043 \\
\text { BootULCI } \\
.0255\end{array}$ \\
\hline
\end{tabular}

Table (5) shows the result of PROCESS Macro analysis of mediating variables. Based on the PROCESS macro analysis, the variable can be verified as a mediating variable if not the indirect effect falls between zero (Hayes, 2012). The indirect effect of this study utilizes bootstrap standard error and confidence interval. From table (5) above we can see the indirect effect of BootLLCI (-0.0771) and BootULCI (.0174) both falls between zero. Thus, the result indicates that job satisfaction does not have any mediation effect on the relationship between extrinsic rewards and employee performance. Last but not least, $\mathrm{H} 4$ hypothesis not supported. 


\section{Summary of Hypothesis Testing}

Table 6: Summary of Hypothesis Testing

\begin{tabular}{|l|l|}
\hline Hypothesis and description & Result \\
\hline $\begin{array}{l}\text { H1: Extrinsic Rewards has a positive significant relationship with job } \\
\text { satisfaction. }\end{array}$ & Supported \\
\hline $\begin{array}{l}\text { H2: Job satisfaction has a positive significant relationship with } \\
\text { employee performance. }\end{array}$ & Not Supported \\
\hline $\begin{array}{l}\text { H3: Extrinsic rewards have a positive relationship with employee } \\
\text { performance. }\end{array}$ & Supported \\
\hline $\begin{array}{l}\text { H4: Job satisfaction has a mediating effect on the relationship } \\
\text { between extrinsic rewards and employee performance. }\end{array}$ & Not Supported \\
\hline
\end{tabular}

Table (6) summarize the result of hypothesis testing. Based on the result of correlation analysis, and PROCESS Macro analysis, the researcher concludes with clear evidence that $\mathrm{H} 1$, $\mathrm{H} 3$ was supported. On the other hand, H2, H4 was not supported in this study.

\section{Discussion and Limitation of the Study}

This study is examining the relationship between extrinsic rewards, job satisfaction, employee performance among employees of the food and beverage industry at Sunway city. Based on the findings of data analysis, the researcher determined various outcomes.

First of all, in the demographic profile researcher found that in this study most of the respondent is the male and most numbers of the respondent are single those age range from 23-32 years old. In addition, the demographic profile also suggests that most of the staff are getting low average income than the standard living in the Selangor area. Interestingly, this research has proven that the $F \& B$ industry working as medium or low skilled workers and mostly foreigners.

Secondly, relying on correlation analysis, the researcher found that extrinsic rewards have a significant, weak positive relationship with job satisfaction and, employee performance. In contrast, job satisfaction has a non-significant, low negative correlation with employee performance.

Thirdly, based on the PROCESS Macro of mediating analysis, the researcher indicates that job satisfaction does no longer have any influence on the relationship between extrinsic rewards and employee performance. However, several researchers have recognized that the mediating effect of job satisfaction relying on various factors such as age, position, extrinsic factors (Huang \& Su, 2016). Few researchers indicate that employees age more than 40 years above shows more satisfaction than young employees in the organization (Ölçer \& Florescu, 2015). As we see from the demographic profile in this study most of the respondents are young age thus, age range might affect the mediating influence of job satisfaction. In addition, Loan (2020) found that higher rank employees in the organization more satisfying compared to the lower position level of employees. Based on this study, we found that most of the respondents of this study are 'waitress/waiter/cashier' those who are facing lots of dissatisfaction in the organization level than higher rank employees as Ast. manager, supervisor. Moreover, According to Jalal and Zaheer (2017), extrinsic rewards can notably impact the mediating effect of employee job satisfaction in the private sector employees. Based on the findings of the study suggests that most of the respondents in this study are getting lower paid than the living standard in Sunway city. Therefore, the researcher 
concludes with clear proof that job satisfaction does not have any mediating impact on the relationship between extrinsic rewards and employee performance.

On the other hand, in this study have some limitation that needs to explain.

Firstly, this study was performed on F\&B employees of Sunway city, thus, future research needs to focus on the bigger sample which can provide a clearer picture of the relationship between extrinsic rewards, job satisfaction, employee performance.

Secondly, this study solely focal point on one of the HR practices as an independent variable to the outcome variable of employee performance, thus, suggesting for future researchers to seem to be for more HR practices to conduct the relationship with employee performance. Thirdly, in this research, the data was gathering for a short period, thus, the researcher suggesting to conduct data collection with more time which will help to find greater responses and accurate results of the study.

In addition, this study research has focused on the mediating impact of job satisfaction on the relationship between the independent variable and dependent variable. The result has proven that job satisfaction does not have any mediating effect on the relationship between the independent variable and dependent variable. Thus, Future research should focus on other variables (i.e., employee motivation, employee commitment, knowledge behaviour) to conduct the mediating effect on the relationship between extrinsic rewards and employee performance.

Moreover, the consequence of this study will help the F\&B owner, general manager, and human resource manager to think about staff rewards and incentives, increasing job satisfaction and improving the average employee performance.

\section{Implications of the Study}

This study provides implications in various ways. The researcher describes the implication of the study based on three areas accordingly, namely; theoretical implications, practical implications, and methodological implications.

Theoretical implications: The first theoretical contribution of this study to utilized job satisfaction as mediating variable. Based on the previous study, we found that job satisfaction as a mediating variable has given scant attention by the researcher to conduct the relationship between extrinsic rewards and employee performance (Riasat et al., 2016). Thus, this study will be a valuable source of reference to conduct the future study those who want to conduct 'job satisfaction as mediating variable on the relationship between extrinsic rewards and employee performance. In addition, this study develops the relationship between extrinsic rewards, job satisfaction, and employee performance. The previous studies found that there is a gap of sufficient studies about the relationship between these variables (Riasat et al., 2016). Thus, by conducting this study, the researcher tried to fulfil this particular gap. Subsequently, this study will develop the literature review, theoretical framework on the relationship between extrinsic rewards, job satisfaction, and employee performance. Hence, this study will be a valuable source of proof that will help the future researcher to develop a theoretical framework of the relationship between extrinsic rewards, job satisfaction, employee performance. 
Practical Implications: Extrinsic rewards is one of the extrinsic motivation factors for employees of any sector. Prior research found that high extrinsic rewards are related to high job satisfaction and employee performance (Riasat et al., 2016). On the other hand, less extrinsic rewards are related to employee dissatisfaction and, low performance (Khan et al., 2013). The findings of the study also determined that F\&B sector employees of Sunway city get less paid than the normal life standard in Selangor. As a result, Employees of the F\&B sector in Sunway city shows less satisfaction about their job and low performance than the demand. Moreover, In this study also found that most of the respondents of this study are foreigners, where they could not receive any additional benefit except basic salary. As a result, foreign employees are less satisfied with their job compare to Malaysian employees. Thus, the findings of the study will be a valuable source to F\&B owners, the Malaysian hospitality industry, and the government to develop extrinsic rewards packages, develop a strategy to keep F\&B staff satisfied and achieve extraordinary performance.

Methodological Implications: The methodological implications of this study to select the sampling and conducting the mediating analysis. To select the sampling, the exact numbers have not been ascertained, so the minimum numbers of samples are 5 times the number of indicators that have been adopting which met the minimum sample limit (Hair et al., 2010). Thus, this sampling technique also can follow by the future researcher if the exact number is unknown or hard to know by that time. Moreover, in this study, the researcher utilizes the PROCESS Macro analysis to conduct the mediating analysis of job satisfaction on the relationship between extrinsic rewards and employee performance. Previously, the researcher utilizes 'Higheracial regression analysis' compare to PROCESS Macro analysis to conduct the mediating analysis. Therefore, the future researcher can get some insights to utilize PROCESS Macro analysis to conduct the mediating analysis.

\section{Conclusion}

This study has examined the relationship between extrinsic rewards, job satisfaction, employee performance among employees in the F\&B industry of Sunway city. The result of the study indicated that the independent variable has a significant positive relationship with the mediator variable and dependent variable. In contrast, the mediating variable does have a relationship with the dependent variable. Moreover, this study also found that mediating variable does not have any influence on the relationship between the independent variable and dependent variable. In the discussion and limitation part, the researcher has explained about limitations and recommendations for future research. Other than that, this study will be beneficial for F\&B owners, general managers, human resource managers, the Malaysian $F \& B$ Industry, the Malaysian government to make valuable policies on rewards and incentives to make employees happier and achieve higher employee performance.

\section{Reference}

Abdullah, N. N., \& Othman, M. B. (2019). Examining the effects of intellectual capital on the performance of Malaysian food and beverage small and medium-sized enterprises. Technology (IJCIET), 10(2), 135-143.

Bank Negara Malaysia Annual Report. (2018). Retrieved from: https://www.bnm.gov.my//bnm-annual-report-2018.

Clifford, J. M. (1985). "The Relative Importance of Intrinsic and Extrinsic Rewards as Determinants of Work Satisfaction", The sociological quarterly, 26(3), 365-385. 
Department of Statistics Malaysia. (2018). Annual Economic Statistics 2018. Retrieved from: https://www.dosm.gov.my/v1/index.php?r=column/cthemeByCat\&cat=456\&bul_id= MWg5UHNIRXFnN2xIWVdDTmErUDV6QT09\&menu_id=b0pIV1E3RW40VWRTUkZocEh YZ1pLUT09

Dienhart, J. R., Gregoire, M. B., Downey, R. G., \& Knight, P. K. (1992). Service orientation of restaurant employees. International Journal of Hospitality Management, 11(4), 331346.

Gould-Williams, J., \& Davies, F. (2005). Using social exchange theory to predict the effects of HRM practice on employee outcomes: An analysis of public sector workers. Public management review, 7(1), 1-24.

Hall, G. W. (2010). Fast food industry employees and job esteem: A descriptive study. Unpublished doctoral dissertation). Capella University.

Hair, J. F., Anderson, R. E., Babin, B. J., \& Black, W. C. (2010). Multivariate data analysis: A global perspective (Vol. 7).

Hair, J. F., Black, W. C., Babin, B. J., Anderson, R. E., \& Tatham, R. (2006). Multivariate data analysis . Uppersaddle River.

Huang, W. R., \& Su, C. H. (2016). The mediating role of job satisfaction in the relationship between job training satisfaction and turnover intentions. Industrial and Commercial Training.

Joo-Ee, G. (2016). Minimum wage and the hospitality industry in Malaysia: An analysis of employee perceptions. Journal of Human Resources in Hospitality \& Tourism, 15(1), 2944.

Jalal, R. N. U. D., \& Zaheer, M. A. (2017). Does job satisfaction mediate the relationship of workload, remuneration and psychological reward with job performance. International Journal of Academic Research in Business and Social Sciences, 7(9), 64-79.

Kilimo, D., Namusonge, G. S., \& Makokha, E. N. (2017). Determinants of intrinsic and extrinsic rewards on employee performance in Kapsara tea factory company Trans Nzoia County Kenya.

Khan, I., Shahid, M., Nawab, S., \& Wali, S. S. (2013). Influence of intrinsic and extrinsic rewards on employee performance: The banking sector of Pakistan. Academic Research International, 4(1), 282.

Loan, L. (2020). The influence of organizational commitment on employees' job performance: The mediating role of job satisfaction. Management Science Letters, 10(14), 3307-3312.

Ölçer, F., \& Florescu, M. (2015). Mediating effect of job satisfaction in the relationship between psychological empowerment and job performance. Theoretical and Applied Economics, 22(3), 111-136.

Riasat, F., Aslam, S., \& Nisar, Q. A. (2016). Do intrinsic and extrinsic rewards influence job satisfaction and job performance? Mediating role of reward system. Journal of Management Info, 11(1), 16-34.

Ramli, A. H. (2019). Compensation, job satisfaction and employee performance in health services. Business and Entrepreneurial Review, 18(2), 177-186. 